\title{
Thermal Characterization of Mixed Virgin-Recycle Acrylonitrile Butadiene Styrene
}

\author{
Cahyo Budiyantoro $^{a}$, Harini Sosiati ${ }^{b}$, Adi Nugroho ${ }^{c}$, Arista Anggariawan ${ }^{d}$ \\ ${ }^{a, b, d}$ Program Studi Teknik Mesin, Fakultas Teknik, Universitas Muhammadiyah Yogyakarta \\ Jalan Brawijaya, Tamantirto, Kasihan, Bantul, DI Yogyakarta, Indonesia, 55183 \\ e-mail: cahyo_budi@umy.ac.id, hsosiati@ft.umy.ac.id, arista.anggariawan.2013@ft.umy.ac.id \\ ${ }^{\mathrm{c}}$ Politeknik ATMI Surakarta \\ JI. Mojo No. 1, Karangasem, Laweyan, Surakarta, Jawa Tengah 57145 \\ e-mail: adi.nugroho@atmi.ac.id
}

\section{Abstrak}

Acrylonitrile butadiene styrene (ABS) adalah bahan plastik yang banyak digunakan pada pembuatan komponen otomotif. Limbah ABS dari industri injection molding berupa sisa potongan runner memiliki kualitas yang baik sebagai campuran dalam siklus proses produksi. Pencampuran ini bermanfaat secara ekonomis untuk mengurangi penggunaan bahan virgin. Salah satu parameter penting dalam proses injeksi adalah sifat thermal untuk menentukan titik lebur yang sesuai, sifat thermal dari campuran bahan daur ulang dan bahan virgin akan mengalami perubahan jika dibandingkan bahan aslinya. Penelitian ini bertujuan untuk mempelajari sifat termal dari bahan acrilonitrile butadiene styrene (ABS) virgin yang dicampur dengan $\mathrm{ABS}$ daur ulang pada variasi $15 \%, 30 \%$, dan $45 \%$ (\% berat bahan daur ulang). Spesimen dibuat menggunakan mesin injeksi molding MEIKI 70 Ton dan dievaluasi sifat termalnya dengan menggunakan Differential Scanning Calorimetry (DSC) sesuai standard ASTM 3418-2015. Hasil uji DSC menunjukkan bahwa nilai glass transition temperature $(\mathrm{Tg})$ pada variasi campuran $15 \%, 30 \%$ dan $45 \%$ masing-masing adalah $104.08{ }^{\circ} \mathrm{C}, 104.63{ }^{\circ} \mathrm{C}$ dan $105.46{ }^{\circ} \mathrm{C}$. Sementara itu, untuk nilai melting temperature $(\mathrm{Tm})$ dari ketiga variasi tersebut masing masing adalah $139,6{ }^{\circ} \mathrm{C}, 139,72{ }^{\circ} \mathrm{C}$ dan $132,2{ }^{\circ} \mathrm{C}$, sehingga dapat disimpulkan bahwa penambahan kandungan daur ulang bahan $A B S$ memberikan peningkatan pada nilai Tg dan penurunan pada nilai Tm meskipun tidak signifikan.

Kata kunci: Acrylonitrile Butadiene Styrene, Daur Ulang, DSC, Glass Transition Temperature, Melting Temperature

\begin{abstract}
Acrylonitrile Butadiene Styrene is a common material for automotive components. ABS industrial waste in the form of a cut off injection-molded runner is a high-quality plastic waste that can be used as additional material in the production cycles. For an economic reason, adding waste material is very beneficial because the amount of virgin material can be minimized. One of the important parameters on the injection molding process is a thermal related parameter; the thermal properties of mix waste-virgin material could be different from those of the virgin material. This research was aimed to evaluate the thermal properties of mix ABS waste-virgin material. The content of waste material was made in 3 variations: $15 \%, 30 \%$, and $45 \%$ (\% wt). The molding specimens were made by using a 70-ton injection molding machine, and the thermal properties were measured by using Differential Scanning Calorimetry (DSC) according to ASTM 3418-2015 standard. The results showed that the glass transition temperature $(\mathrm{Tg})$ at waste content of $15 \%, 30 \%$, and $45 \%$ are $104.08{ }^{\circ} \mathrm{C}, 104.63$ ${ }^{\circ} \mathrm{C}$, and $105.46{ }^{\circ} \mathrm{C}$, respectively, whereas their respective melting temperatures were $139.6{ }^{\circ} \mathrm{C}, 139.72{ }^{\circ} \mathrm{C}$ dan $132.2{ }^{\circ} \mathrm{C}$. Those results were lower than the temperature of virgin material. It can be said that the waste content gives effect on increasing of $\mathrm{Tg}$ and reducing of Tm.
\end{abstract}

Keywords: Acrylonitrile Butadiene Styrene, Recycle, DSC, Glass Transition Temperature, Melting Temperatures 


\section{INTRODUCTION}

Acrylonitrile-butadiene-styrene (ABS) is one of the most popular engineering thermoplastics. It is an amorphous copolymer type of plastic that builds out of three monomers i.e., styrene-acrylonitrile - and polybutadiene (PB) rubber. ABS is commonly used in automotive industries, in electrical and electronic types of equipment, telecommunication instruments, and other products. As a consequence of the increasing usage of $A B S$ material, a large volume of disposal arises and gives impact on the environment. The recycling of ABS is one of the most effective ways to reduce the negative effects of waste plastics on the environment. The recycling process reduces both the quantities of plastics sent to landfills and raw material extraction. The recycling of ABS waste becomes challenging for academia and plastic industries. Most of ABS waste is considered as high-quality waste, especially the waste coming from injection molding cold runners. They have an excellent balance in properties, as good as the product that comes out of the mold so that they can be directly recycled and mixed with the virgin material. However, the properties of recycled materials are usually worse than those of the virgin ones, but mixing both types of material conditions is very beneficial from the economic point of view because the amount of the virgin material can be reduced.

Even though a recycled material would show lower properties, a good balance between properties and processability is more important in recycled material. Thermal properties are one of the material properties that can be affected by the amount of waste content. In the case of virgin material, users can easily get information about those properties from material suppliers, but the thermal data of mixed ABS waste-virgin material are rarely found. In fact, information on thermal properties is very useful for processing the plastic product; one needs to know the melting temperature and glass transition temperature to produce a high quality of the product. There are various methods for analyzing thermal properties of a plastic material such as Thermogravimetric Analysis (TGA), Dynamic mechanical analysis (DMA), Fourier transform infrared spectroscopy (FT-IR), and differential scanning calorimetry (DSC). Those methods are destructive types but proven to be very useful for assessing the degradation of material [1]. Among all these methods, DSC and TGA are the most frequently used techniques in the thermal analysis [2,3].

Some research related the thermal properties of recycling ABS has been done. Brennan et al. [4] investigated the effects of the recycling and blending of ABS and high impact polystyrene on the mechanical properties. The result showed that changes in glass-transition temperature, tensile strength, and tensile modulus in recycled ABS were only small, but the strain to break and impact strength were reduced significantly. Regarding the thermal properties of a material, calorimetry is a suitable technique to establish a relation between temperature and their specific physical and chemical properties. This method also provides a direct determination of the enthalpy associated with the process [5].

A technical guide for mixing recycled and virgin $A B S$ is already prepared by $A B S$ TORAY. The mixing compositions proposed by this material supplier are as follow: $100 \%$ virgin $A B S, 90 \%$ virgin $A B S+10 \%$ recycled $A B S, 70 \%$ virgin $A B S+30 \%$ recycled, and $50 \%$ virgin $A B S+50 \%$ recycled ABS [6]. The mechanical properties, as well as physical properties such as tensile strength, tensile modulus, impact strength, and melt flow index, have already provided by TORAY. A blending of virgin/waste polymer is the most common method for increasing the value of waste material; however, the thermal data of blending results are rarely found.

Roziafanto [7] and Peydro [8] investigated the changes in glass transition temperature of $A B S$ + regrind PMMA and ABS + HIPS by using Differential Scanning Calorimetry (DSC). Those research above only concerned to the miscibility of the different components.

In this paper, the aim is to investigate the thermal properties of mixed virgin $A B S$ and waste ABS, such as glass transition (Tg), melting behavior, crystallization behavior, and specific heat for different weight percentages of waste material using differential scanning calorimetry (DSC). The waste content varied from $15 \%, 30 \%$, and $45 \%$. The results were compared with the properties of $100 \%$ virgin ABS and will be beneficial for industries that use recycled materials. 


\section{Methods}

\subsection{Material and Preparation}

The virgin $A B S$ used in this work was $A B S$ Toyolac $B 1$, an injection-molding grade material made by Toray Plastics (Malaysia) Sdn. Bhd [6]. Waste ABS was obtained from the same material, but it has been 3 times reprocessing in the injection molding machine, the result of each process was cut into smaller size by using crusher machine and then finally shaped into dumbbell specimen. There was 4 variation of specimen preparation, as shown in Table 2.1.

Table 2.1. Variation of waste ABS content

\begin{tabular}{cccc}
\hline \multirow{2}{*}{ No } & Sample & \multicolumn{2}{c}{ Composition (\% weight) } \\
\cline { 3 - 4 } 1. & Virgin ABS 100\% & 100 & Recycled ABS \\
2. & ABS Virgin $85 \%+$ & 85 & - \\
ABS Recycle 15\% & ABS & 15 \\
3. & $\begin{array}{c}\text { ABS Virgin 70\%+ } \\
\text { ABS Recycle 30\% }\end{array}$ & 70 & 30 \\
4. & $\begin{array}{c}\text { ABS Virgin 55\%+ } \\
\text { ABS Recycle 45\% }\end{array}$ & 55 & 45 \\
\hline
\end{tabular}

Due to its hygroscopic property, ABS was dried for at least $3 \mathrm{~h}$, at $90{ }^{\circ} \mathrm{C}$ to minimize moisture content prior to the injection molding process. The recommended moisture content for "TOYOLAC" general-purpose grades is less than $0.1 \%$ [6]. The specimens were shaped in a single cavity mold by using Meiki Injection Molding, which had a maximum clamping force of 70 tons. Table 2.2 is the processing parameter data.

Table 2.2. Processing parameter

\begin{tabular}{lcc}
\hline \multicolumn{1}{c}{ Parameter } & Value & Unit \\
\hline Melt temperature (hopper to the nozzle) & $180-230$ & ${ }^{\circ} \mathrm{C}$ \\
Mold temperature & 30 & ${ }^{\circ} \mathrm{C}$ \\
Injection pressure & 140 & bar \\
Holding pressure & 100 & bar \\
Holding time & 3 & seconds \\
Cooling time & 10 & seconds \\
\hline
\end{tabular}

\subsection{Differential Scanning Calorimetry Measurement}

Differential scanning calorimeters (DSC) measures the change in the thermal and micro properties of the sample as a function of temperature over time. Thermal properties of the different varieties of waste ABS were studied by using a Mettler-Toledo 821 DSC (Mettler Toledo Inc., Schwarzenbach, Switzerland), according to ASTM D3418-15 standard. At first, $5-7 \mathrm{mg}( \pm 0.01 \mathrm{mg})$ samples were subjected to first heating from approximately $50^{\circ} \mathrm{C}$ below $\mathrm{Tg}$ until $30^{\circ} \mathrm{C}$ above $\mathrm{Tm}$ at a heating rate of $10^{\circ} \mathrm{C} / \mathrm{min}$, hold for 5 minutes. This stage then followed by slow cooling to remove thermal history, the specimen was cooled down $50{ }^{\circ} \mathrm{C}$ below crystallization temperature at cooling rate of $10^{\circ} \mathrm{C} / \mathrm{min}$, and held again for 5 minutes. The first step was repeated as the second heating. All the endothermic (glass transition temperature and melting temperature) measurements were taken from the second heating stage after removing previous thermal history, and the exothermic measurements (crystallization temperature) were taken from the first cooling scan [9].

\section{RESULtS AND Discussion}

3.1 Glass Transition Temperature

During DSC heating, it is possible to measure the glass transition temperature $(\mathrm{Tg})$ and the melting temperature $(\mathrm{Tm})$ of the specimens. Figure 3.1 shows the thermogram of all 
waste content variations that depicted heating scans as a function of temperature. The first declining curve on the thermogram indicates the $\mathrm{Tg}$ of $\mathrm{ABS}$, while the peak on the shaded area indicates the Tm. Also, the Tg of ABS are listed in Table 3.1. From Table 3.1, it can be seen that the $\mathrm{Tg}$ of $\mathrm{ABS}$ in all variation are nearly constant at around $105{ }^{\circ} \mathrm{C}$ and are independent of the waste variation.
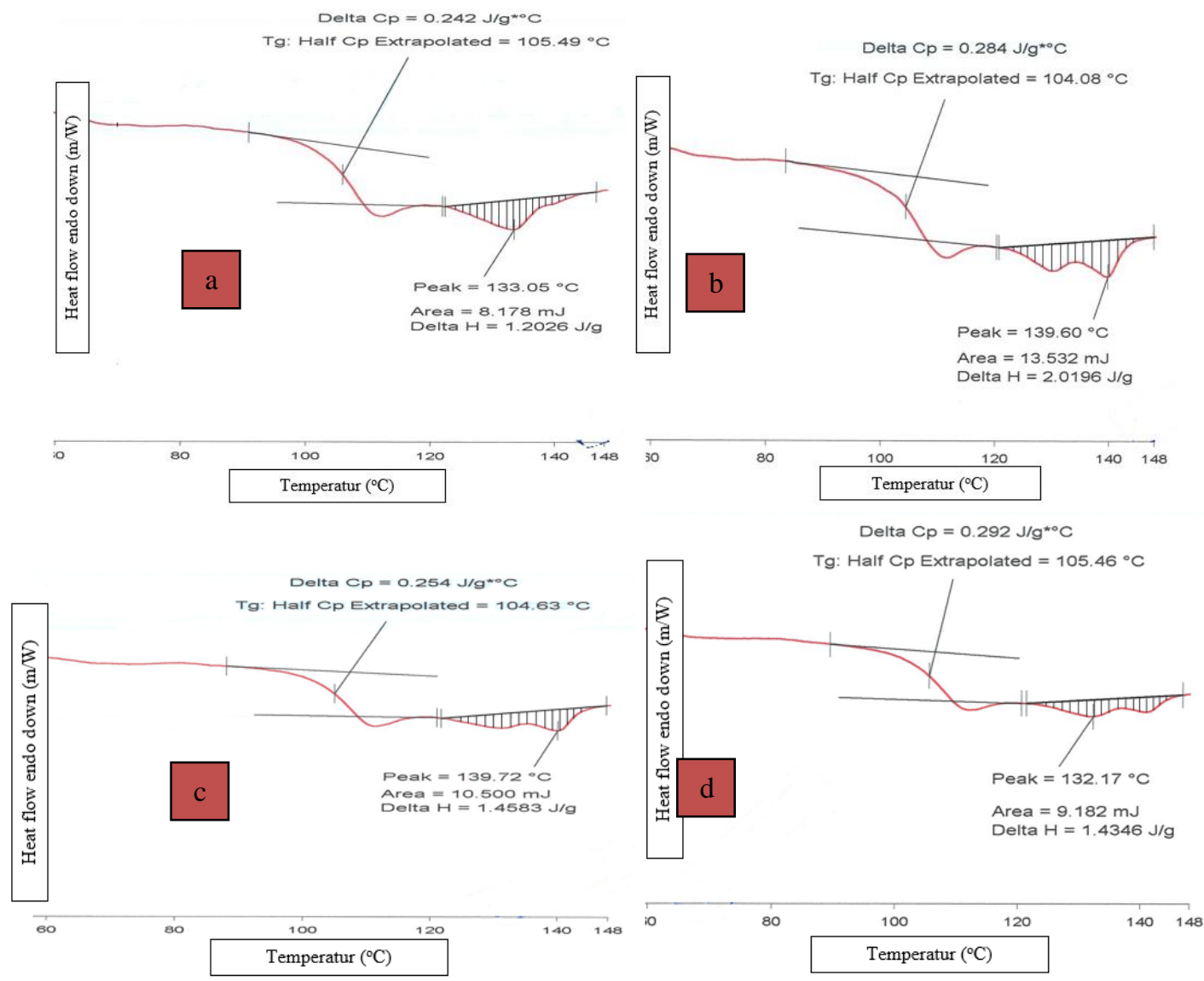

Figure 3.1. DSC Thermogram of all variation:a) ABS virgin 100\%; b) ABS virgin $85 \%+$ recycle $15 \%$; c) $A B S$ virgin $70 \%+$ recycle $30 \%$; d) $A B S$ virgin $55 \%+$ recycle $45 \%$

Table 3.1. Enthalpy obtained from DSC heating scans

\begin{tabular}{cc}
\hline Sample & $\Delta \mathrm{H}(\mathrm{J} / \mathrm{g})$ \\
\hline Virgin ABS 100\% & 1,2026 \\
ABS Virgin 85\% + ABS Recycle 15\% & 2,0196 \\
ABS Virgin 70\% + ABS Recycle 30\% & 1,4583 \\
ABS Virgin 55\% + ABS Recycle 45\% & 1,4346 \\
\hline
\end{tabular}

Figure 3.2 clearly informs that the presence of waste ABS has no significant influence on the glass transition temperature, and practically, $\mathrm{Tg}$ is used as a limit of product service temperature. It can be said that 3 times recycling for high-quality waste at a certain amount is still allowed. According to Perez et al. [10], the number of ABS reprocessing does not affect their Tg significantly. 


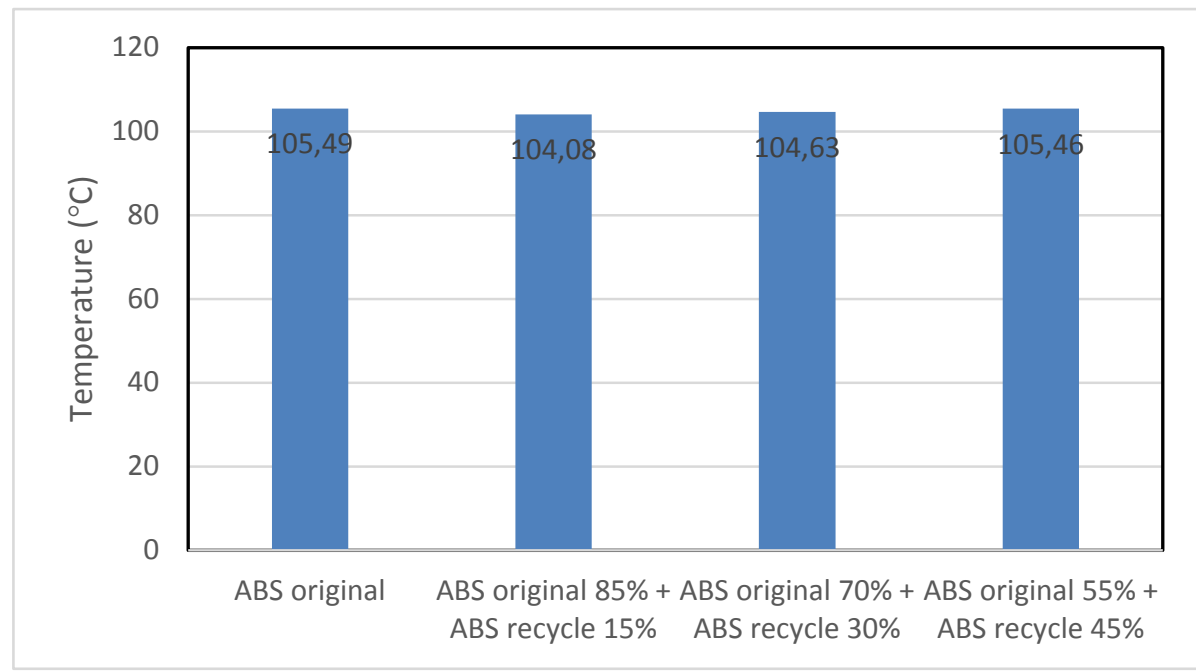

Figure 3.2. Glass transition temperature in all variation

Wei et al. [11] stated that in the case of the DSC thermogram, which has two peaks, the melting temperature is chosen from the curve with the highest peak. The Tm value in a material is high because the bonds between molecules are strong so that the heat energy needed to release bonds between molecules is large. The constituents in materials that have good heat resistance increase the Tm. Material that has a weak bonding between molecules is easier to release by heat energy. Figure 3.3 shows that melting temperature gradually increase with increasing waste content. Tm of virgin material is $133.05{ }^{\circ} \mathrm{C}, 139.6{ }^{\circ} \mathrm{C}$ for $15 \%$ waste content, and the maximum value is $139.72{ }^{\circ} \mathrm{C}$, with $30 \%$ waste content. When the waste content becomes higher (45\%), Tm then drops down to $132.17^{\circ} \mathrm{C}$. These results are relevant in research conducted by Perez et al., where the addition of recycling material decreases the Tm value even though it is not too significant.

Interestingly, all of the shaded areas in figure 3.1 show double peaks, except the area of virgin material, which has only a single peak. The formation of a single peak is possible because the virgin material absorbs thermal energy constantly, without involving waste material.

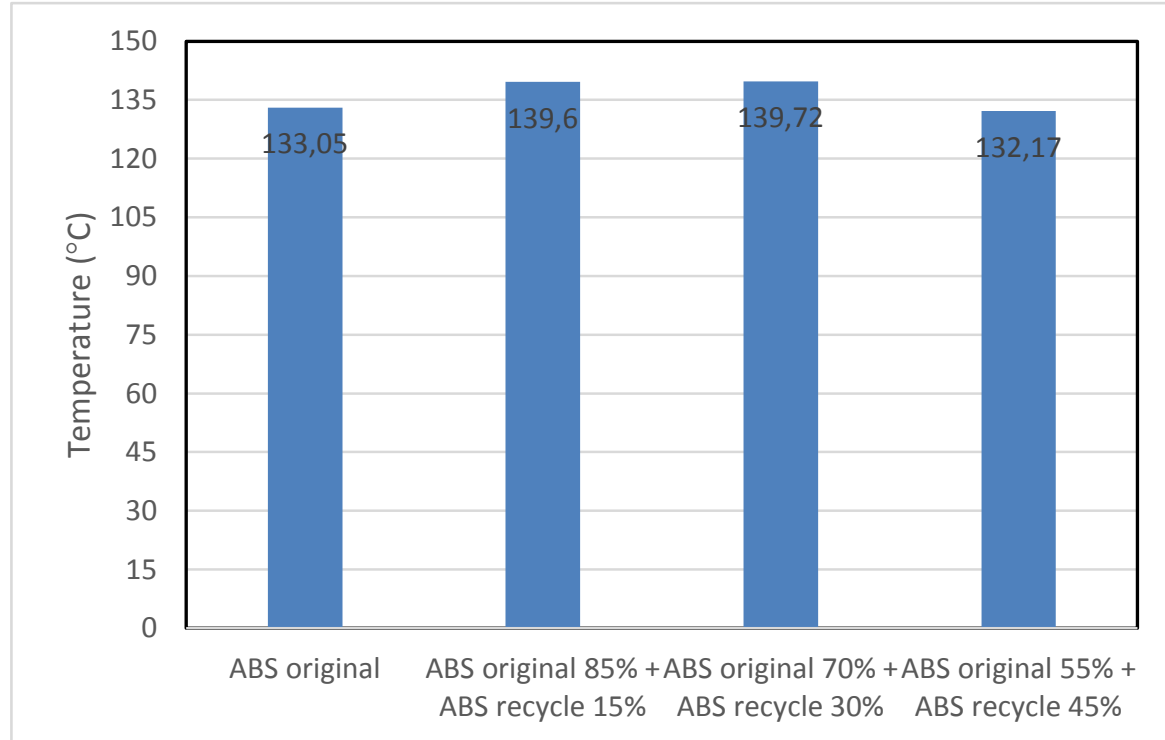

Figure 3.3. Melting temperature in all variation 
On the other hand, the double peaks that occurred on mixed virgin-waste ABS, are formed by 2 times thermal energy absorption. The peaks are built by simultaneous heating and crystallization effect of waste material followed by the melting of virgin material on a higher temperature. Raimo [12] explained that the melting temperature is also linearly proportional to the size of crystal spherulite. The second peak can also be formed by the act of contaminants such as oil or mold release agents that may stick on the mold. Araújo et al. [13] explained that the purity of the material is inversely proportional to its melting point. The higher melting temperature indicates the more impurities in the material because the impurity has a larger crystal size. In the research of mixing ABS virgin + ABS recycle, the first peak is a melting point from ABS material, while the second peak is a melting point from the impurity. This impurity may come from recycled material.

The value of the shaded area represents the amount of energy needed to release the molecular bonding of plastic material. This value proportionally corresponds to the $\Delta H$ [14]. $\Delta \mathrm{H}$ on the DSC thermogram is the enthalpy change calculated by the DSC software. Enthalpy is the energy released or absorbed during a reaction; the change in enthalpy $\Delta \mathrm{H}$ can be calculated by setting a reference point. A positive $\Delta H$ is an endothermic reaction, while a negative $\Delta \mathrm{H}$ is an exothermic reaction. The results in Table 3.1 show that the enthalpy of melting (exothermic reaction) of $A B S$ is affected by the presence of the recycled ABS component. The enthalpy of melting of the mixed ABS decreases with the increase in ABS waste content but still higher than that of the virgin material.

\section{Conclusion}

In this study, the waste ABS taken from runner scrap of injection molding material has been successfully mixed with various content. A change in the thermal properties was characterized. The various experimentation outputs are summarized as follows: (a) The glass transition temperature of mixed ABS remains constant for all compositions, (b) DSC thermogram of the ABS mixture shows the presence of double peaks. The first peak is influenced by the content of recycled material acting as impurities, while the second peak is calculated as the melting point of the material, and (c) Melting Enthalpy of the mixed ABS decrease almost linearly with the increase in ABS waste content.

Because $\mathrm{Tg}$ is generally used as the basis of product service temperature, it can be stated that the recycled material content of up to $30 \%$ is still suitable for manufacturing ABS products. However, the recycled material must have good quality; for example, the recycled material comes from the runner resulting from the injection molding process.

\section{ACKNOWLEDGMENT}

The authors are thankful to the Mechanical Engineering Departement of Universitas Muhammadiyah Yogyakarta for financial support.

\section{REFERENCES}

[1] A. Cucos, P. Budrugeaca, L. Miu, S. Mitrea, and G. Sbarcea, "Dynamic mechanical analysis (DMA) of new and historical parchments and leathers: correlations with DSC and XRD," Thermochim Acta, vol. 516, no. 1- 2, pp. 19-28, 2011.

[2] A. Das, B. K. Satapathy, "Structural, thermal, mechanical and dynamic mechanical properties of cenosphere filled polypropylene composites," Mater Des., vol. 32, no. 3, pp. 1477-84, 2011.

[3] H. Essabir, A. Elkhaoulani, K. Benmoussa, R. Bouhfid, F. Z. Arrakhiz, and A. Qaiss, "Dynamic mechanical thermal behavior analysis of doum fibers reinforced polypropylene composites," Mater Des., vol. 51, pp. 780-788, 2013.

[4] L. B. Brennan, D. H. Isaac, and J. C. Arnold, "Recycling of acrylonitrile-butadienestyrene and high-impact polystyrene from waste computer equipment," J Appl Polym Sci., vol. 86, pp. 572-578, 2002. 
[5] M. A. Sohel, A. Mandal, A. Mondal, S. Pan, and A. SenGupta, "Thermal analysis of ABS/PA6 polymer blend using differential scanning calorimetry," J Therm Anal Calorim., vol. 129, no. 3, pp. 1689-1695, 2017.

[6] Toray Plastics (Malaysia) Sdn. Bhd. ABS Resin "TOYOLAC" Technical Guide. Malaysia. Toray. 2017.

[7] Roziafanto AN. Studi Pemanfaatan PMMA Regrind Yang Diblending dengan ABS Ditinjau dari Perubahan Sifat Mekanik. Tesis. Universitas Indonesia. 2010

[8] M. A. Peydro, D. Juarez, S. Sanchez-Caballero, and F. Parres, "Study of the thermal properties of acrylonitrile butadiene styrene - high impact polystyrene blends with styrene ethylene butylene styrene," Annals of The University of Oradea, vol. 22, no. 1, pp. 273-276, 2013.

[9] K. S. Boparai, R. Singh, F. Fabbrocino, and F. Fraternali, "Thermal characterization of recycled polymer for additive manufacturing applications," Composites Part B: Engineering, vol. 106, pp. 42-47, 2016.

[10] J. M. Pérez, J. L. Vilas, J. M. Laza, S. Arnáiz, F. Mijangos, E. Bilbao, and L. M. Leon, "Effect of reprocessing and accelerated weathering on ABS properties," $J$ Polym Environ., vol. 18, no. 1, pp. 71-78, 2010.

[11] C. L. Wei, M. Chen, and F. E. Yu, "Temperature modulated DSC and DSC studies on the origin of double melting peaks in poly(ether ether ketone)," Polymer, vol. 44, no. 26, pp. 8185-8193, 2003.

[12] M. Raimo, "Growth of spherulites: foundation of the DSC analysis of solidification," ChemTexts, vol. 1, no. 13, 2015.

[13] A. A. S. Araújo, M. D. S. Bezerra, S. Storpirtis, and J. D. R. Matos, "Determination of the melting temperature, heat of fusion, and purity analysis of different samples of zidovudine (AZT) using DSC," Brazilian Journal of Pharmaceutical Sciences, vol. 46, no. 1 , pp. 37-43, 2010.

[14] D. Fabri, J. Guan, and A. Cesàro," Crystallisation and melting behaviour of poly (3hydroxybutyrate) in dilute solution: towards an understanding of physical gels," Thermochimica Acta, vol. 321, no. 1-2, pp. 3-16, 1998. 